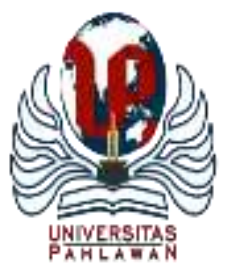

Edukatif : Jurnal Ilmu Pendidikan Volume 3 Nomor 6 Tahun 2021 Halm 3808 - 3815

EDUKATIF: JURNAL ILMU PENDIDIKAN

Research \& Learning in Education

https:/ledukatif.org/index.php/edukatif/index

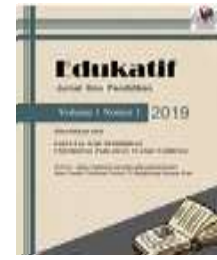

\title{
Analisis Kalimat Imperatif pada Pidato Nadiem Makarim Rekomendasi sebagai Bahan Ajar Teks Pidato Persuasif SMP
}

\author{
Siti Jubaedah $^{1 凶}$, Hendra Setiawan ${ }^{2}$, Ferina Meliasanti ${ }^{3}$ \\ Universitas Singaperbangsa Karawang, Indonesia ${ }^{1,2,3}$ \\ E-mail : jubedd12345@ gmail.com ${ }^{1}, \underline{\text { hendra.setiawan@ @ fkip.unsika.ac.id }}^{2},{\underline{\text { ferina.meliasanti@ } \text { fkip.unsika.ac.id }^{3}}}^{3}$
}

\begin{abstract}
Abstrak
Penelitian ini dilakukan untuk mendeskripsikan penggunaan Kalimat Imperatif pada Pidato Nadiem Makarim dalam channel Kemendikbud RI serta rekomendasi sebagai Bahan Ajar Teks Pidato Persuasif di SMP. Pendekatan yang digunakan dengan deskriptif kualitatif dengan analisis Teknik Bagi Unsur (BLU). Jenis kalimat imperatif yang digunakan meliputi (1) kalimat imperatif halus terdapat beberapa penanda kalimat yaitu kata coba, tolong, dan silakan. (2) Kalimat imperative permintaan ditandai dengan kata mohon. (3) Kalimat imperatif ajakan menggunakan penanda kata ayo, mari. (4) Kalimat imperatif larangan ditandai oleh kata jangan. Direkomendasikan penggunaan kalimat imperatif halus, Kalimat imperative permintaan, Kalimat imperatif ajakan dan Kalimat imperatif larangan sebagai bahan ajar teks pidato persuasif Sekolah Menengah Pertama (SMP) serta menambahkan kalimat imperative pemberian izin, kalimat imperative sebagai anjuran dan kalimat imperative sebagai selamat. Kesimpulan penelitian ini terdapat empat kalimat imperatif dalam pidato Nadiem Makarim yang dapat dijadikan rekomendasi bahan ajar teks pidato persuasif serta dapat ditambah dengan imperative pemberian izin, kalimat imperative sebagai anjuran dan kalimat imperative sebagai selamat yang tidak terdapat pada pidato Nadiem Makarim.
\end{abstract}

Kata Kunci: kalimat imperative, Pidato Nadiem Makarim, teks pidato persuasif.

\begin{abstract}
This study was conducted to describe the use of Imperative Sentences in Nadiem Makarim's Speech in the RI Ministry of Education and Culture channel and recommendations as Teaching Materials for Persuasive Speech Texts in Junior High Schools. The approach used is descriptive qualitative with the analysis of the Elements Division (BLU). The types of imperative sentences used include (1) subtle imperative sentences where there are several sentence markers, namely the words try, please, and please. (2) The imperative sentence request is marked with the word bag. (3) The imperative sentence of an invitation uses the word marker let's go, let's. (4) The imperative sentence of prohibition is marked by the word do not. It is recommended to use subtle imperative sentences, request imperative sentences, invitation imperative sentences, and prohibitive imperative sentences as teaching materials for junior high school (SMP) speech texts and add permission imperative sentences, imperative sentences as suggestions, and imperative sentences as congratulations. The conclusion of this study is that there are four imperative sentences in Nadiem Makarim's speech that can be used as recommendations for teaching text materials and can be added to the imperative of giving permission, imperative sentences as suggestions, and imperative sentences as congratulations which are not found in Nadiem Makarim's speech.
\end{abstract}

Keywords: imperative sentence, Nadiem Makarim's speech, persuasive speech text.

Copyright (c) 2021 Siti Jubaedah, Hendra Setiawan, Ferina Meliasanti

$\triangle$ Corresponding author:

Email : jubedd12345@gmail.com

DOI : https://doi.org/10.31004/edukatif.v3i6.1246

ISSN 2656-8063 (Media Cetak)

ISSN 2656-8071 (Media Online)

Edukatif : Jurnal Ilmu Pendidikan Vol 3 No 6 Tahun 2021 p-ISSN 2656-8063 e-ISSN 2656-8071 
3809 Analisis Kalimat Imperatif pada Pidato Nadiem Makarim Rekomendasi sebagai Bahan Ajar Teks Pidato Persuasif SMP - Siti Jubaedah, Hendra Setiawan, Ferina Meliasanti

DOI: https://doi.org/10.31004/edukatif.v3i6.1246

\section{PENDAHULUAN}

Bahasa Indonesia memiliki pengaruh yang besar terhadap penggunaan teknologi. Bahasa yang digunakan dalam keseharian adalah penggunaan bahasa dalam jejaring sosial, yang berdampak pada masyarakat untuk berinteraksi lebih bebas. Salah satunya adalah jejaring sosial YouTube yang terkenal, yang juga membawa banyak hal positif. Yang saat ini sedang ramai diperbincangkan di bidang pendidikan adalah video Nadiem Makarim yang diunggah ke kanal Kementerian Pendidikan dan Kebudayaan RI. Kompetensi dalam pidato Nadiem Makarim dapat membuat masyarakat, khususnya pendidikan Indonesia terarah sesuai yang diharapkan.

Sayangnya hal ini malah jarang diketahui dan disepelekan oleh masyarakat khususnya para guru di Indonesia. Sebagian masyarakat dan guru di Indonesia belum mengetahui betapa pentingnya pidato Nadiem Makarim. Hingga berdampak negatif bagi guru, misalnya masih banyak guru yang tidak mampu mengelola kelas dengan baik, meskipun dalam pidato Nadiem Makarim mengajak seluruh guru Indonesia untuk melakukan perubahan kecil, salah satunya "ajaklah kelas berdiskusi bukan hanya mendengar", Nadiem Makarim memiliki harapan yang tinggi jika guru melakukan ini pada saat yang sama, maka Indonesia pasti akan bergerak maju. Oleh karena itu, pentingnya pidato Nadiem Makarim bagi pendidikan Indonesia.

Dalam pidato Nadiem Makarim yang diunggah dalam channel Kemendikbud RI sebagai sumber kajian, karena didalam pidatonya memuat pembahasan yang positif sehingga akan mempengaruhi kehidupan yang baik untuk masyarakat dan guru di Indonesia. Didalam pidato Nadiem Makarim tersebut kalimat imperatif digunakan sebagai sarana untuk mengungkapkan pendapatnya yang bertujuan untuk mempengaruhi pendengar. Hal tersebut sangat menarik untuk dijadikan penelitian, penulis tertarik untuk melakukan sebuah penelitian pada pidato Nadiem Makarim yang di unggah dalam channelKemendikbud RI. Didalam pidatonya tersebut, penulis menemukan penggunaan kalimat imperatif yang dapat mempengaruhi pendengar.

(Finoza, 2013) menjelaskan bahwa dalam kalimat perintah (imperatif) digunakan jika penutur ingin menyuruh atau melarang orang berbuat saesuatu. Dalam bahasa lisan,intonasi atau nada tuturannya diakhir menurun. Dalam bahasa tulisan, kalimat ini diakhiri dengan tanda seru atau titik. Kalimat perintah dapat dibedakan menjadi. kalimat perintah halus, kalimat perintah permohonan, kalimat perintah ajakan atau harapan, kalimat perintah larangan, dan kalimat perintah pembiaran. Sedangkan (Chaer, 2010) berpendapat bahwa kalimat dasar adalah kalimat yang meminta audiens atau pembaca untuk memerlukan suatu kegiatan. Kalimat dasar dapat dipisahkan menjadi perintah, himbauan, dan larangan.

Dilihat dari berbagai situasi yang terjadi, sebaiknya kita menggunakan kalimat imperatif dengan lebih hati-hati. Hal ini memanifestasikan dirinya dalam penggunaan berbagai kalimat imperatif, mengidentifikasi kemampuan seseorang untuk membedakan penggunaan kalimat imperatif sesuai dengan tujuannya. Agar tidak menimbulkan kesalahpahaman antara pembicara dan pendengar. Menyampaikan kalimat dasar untuk memprediksi jawaban dalam bentuk aktivitas pembicara. Sesuai dengan ciri formalnya, kalimat ini memadukan berbagai desain nada dari desain suara kalimat dan kalimat tanya (Ramlan, 2010).

Seperti yang kita ketahui, bahwa kalimat imperatif dipelajari di sekolah. Siswa dijarkan untuk membuat berbagai jenis teks. Salah satunya teks pidato persuasif. Didalam pembelajaran bahasa Indonesia terdapat materi teks pidato persuasif. Berdasarkan kurikulum 2013 yang tertuang didalam silabus bahasa Indonesia, mengenai materi teks pidato persuasif yang dipelajari disekolah menengah pertama (SMP) kelas IX. Hasil analisis kalimat imperatif pada pidato Nadiem Makarim yang diunggah dalam channel Kemendikbud RI. Dapat direkomendasikan sebagai bahan ajar teks pidato persuasive. Menurut Rakhmat (2000: 102) (dalam (Heryanto, 2019)) mengatakan bahwa Pidato persuasi proses mengaruhi pendapat, sikap, dan tindakan orang dengan mengunakan manipulasi psikologis, sehingga orang tersebut bertindak atas kehendaknya sendiri untuk menyetujui. 
3810 Analisis Kalimat Imperatif pada Pidato Nadiem Makarim Rekomendasi sebagai Bahan Ajar Teks Pidato Persuasif SMP - Siti Jubaedah, Hendra Setiawan, Ferina Meliasanti

DOI: https://doi.org/10.31004/edukatif.v3i6.1246

Sehubungan dengan penelitian analisis kalimat imperatif yang serupa pernah dilakukan oleh (Anak Agung Sri Darmawanti, Made Sri Indriani, 2019) dengan judul "Analisis Kalimat Imperatif dalam video tutorial Skincare Clarin Hayes di Youtube dan relevansinya pada pembelajaran teks prosedur di SMA". (Nurul Fahmi, Saifuddin Mahmud, 2018) yang berjudul "Analisis kalimat Imperatif yang digunakan Guru dalam Pembelajaran Bahasa Indonesia di SMA Inshafuddin Bandar Aceh”, (Lindawati, 2015) Kalimat Imperatif Bahasa Kepulauan Tukang Besi, (Nuryani, 2014) Kalimat Imperatif dalam Bahasa Jawa, (Izhar, 2015) Pengungkapan Makna Imperatif dalam Komunikasi Jual Beli, Astri (2020) dengan Judul Kalimat Imperatif Dalam Bahasa Batak Toba Desa Mela Kecamatan Tapian Nauli Kabupaten Tapanuli Tengah, (Saputri, 2017) dengan judul Penggunaan Kalimat Imperatif oleh Guru dalam kegiatan pembelajaran Bahasa Indonesia di SMP Negeri 13 Kota Magelang.

Adapun dalam penelitian ini penulis menemukan perbedaan objek kajianya karena yang menjadi sasaran peneliti ini adalah pidato Nadiem Makarim dalam channel Kemendikbud RI. Dan persamaan dalam penelitian tersebut dengan penelitian yang penulis lakukan adalah sama-sama membahasa kalimat imperatif.

Dari uraian diatas, penulis akan melakukan penelitian dalam pidato Nadiem Makarim dalam Channel Kemendukbud RI. Penulis akan mengkaji permasalahan dengan menggunakan teori sintaksis sebagai landasan teori. Permasalahan yang dikaji dalam penelitian ini bertujuan untuk mendeskripsikan penggunaan Kalimat Imperatif pada Pidato Nadiem Makarim dalam channel Kemendikbud RI serta untuk mendeskripsikan rekomendasi kalimat imperatif pada Pidato Nadiem Makarim dalam channel Kemendikbud RI Sebagai Bahan Ajar Teks Pidato Persuasif di SMP

\section{METODE PENELITIAN}

Pendekatan yang digunakan dalam penelitian ini merupakan pendekatan deskriptif dimana penelitian untuk menyelidiki keadaan, kondisi atau hal lain-lain yang sudah disebutkan, yang hasilnya dipaparkan dalam bentuk laporan penelitian (Arikunto, 2010) dan bersifat kualitatif yang bermaksud untuk memahami fenomena tentang apa yang dialami oleh subjek penelitian (Lexy J Moleong, 2016). Subjek dalam penelitian ini adalah Pidato Nadiem Makarim yang diunggah dalam Channel Kemendikbud RI.

Teknik pengumpulan data dalam penelitian ini adalah teknik dokumentasi dimana merupakan catatan peristiwa yang yang sudah berlalu (Sugiyono, 2018), teknik simak dimana metode simak yang digunakan dalam penelitian bahasa dengan cara menyimak penggunaan bahasa pada objek yang akan diteliti (Sudaryanto, 2015) dan teknik catat dimana pencatatan itu dapat dilakukan langsung ketika teknik pertama atau kedua selesai digunakan, dierapkan dengan menggunakan alat tulis tertentu (Sudaryanto, 2015).

Metode analisis data yang digunakan dalam menentukan penggunaan kalimat imperative yaitu metode agih atau juga bisa disebut sebagai Teknik Bagi Unsur (BLU). Adapun tahapan penelitian langkah awal dalam menganalis data yaitu dengan mengumpulkan Pidato Nadiem Makarim yang diunggah dalam channel Kemendikbud RI. Menyimak videonya dengan teliti dan mencatat. Setelah data terkumpul dikelompokan berdasarkan bentuk kalimat imperatif, struktur kalimat imperatif dan jenis kalimat imperatif yang sesuai, dan menggabungkan hasil analisis dengan pernyataan, kategori atau kriteria tertentu untuk menentukan makna dari data yang dikumpulkan untuk menjawab permasalahan dalam penelitian.

Adapun pedoman instrument penelitian analisis bentuk kalimat imperative dimana berisi perintah dan dapat mempengarui orang lain untuk melakuka suatu tindakan yang dikehendaki (mengharap adanya respon dari pembaca), dengan indikator menurut (Alwi Dkk, 2011) yaitu (1) Berisi perintah dan dapat mempengarui orang lain untuk melakuka suatu tindakan yang dikehendaki (mengharap adanya respon dari pembaca), (2) Pemakaian pertikel penegas, penghalus, dan tanda kata tugas ajakan, persilahan dan larangan. (3) Susunan inversi yang urutanya menjadi tidak selalu terungkap subjek dan predikanya. (4) Kalimat yang terdiri atau predikat perba dasar atau adjektiva atau pun frasa preposisional. Saja yang sifatnya taktransitif. (5) Kalimat lengkap yang berpredikat verba taktransitif atau transitif. 
3811 Analisis Kalimat Imperatif pada Pidato Nadiem Makarim Rekomendasi sebagai Bahan Ajar Teks Pidato Persuasif SMP - Siti Jubaedah, Hendra Setiawan, Ferina Meliasanti

DOI: https://doi.org/10.31004/edukatif.v3i6.1246

Adapun pedoman instrumen penelitian analisis klasifikasi jenis kalimat imperatif menurut (Alwi Dkk, 2011) yaitu (1) Kalimat imperatif taktransitif ditandai dengan berperdikat verba dasar, frasa adjektival, dan frasa verbal yang berprefiks ber atau meng ataupun preposisional. (2) Kalimat imperatif transitif ditandai bahwa kalimat dapat dianggap berbentuk pasif ialah kenyataan bahwa lawan bicara yang dalam kalimat deklaratif berfungsi sebgai subjek pelaku sasaran dalam kaliamt imperatif. (3) Kalimat imperatif halus ditandai dengan penegasan partikel-lah, Memiliki makna suruh dipakai untuk menghaluskan, adanya penggunaan kata tolong, coba, silahkan, sudilah dan kiranya. (4) Kalimat imperatif permintaan ditandai dengan pemakaian penanda kesantunan ayo, mari dan hendaknya, penambahan penegasan-lah sehingga bentukny amenjadi ayolah dan marilah. (5) Kalimat imperatif ajakan dan harapan ditandai dengan pemakaian penanda kesantunan ayo, mari dan hendaknya, penambahan penegasan-lah sehingga bentuknya amenjadi ayolah dan marilah. (6) Kalimat imperatif larangan ditandai dengan adanya kata jangan, dapat disertai dengan pemakaian partikel-lah sehingga bentuknya menjadi janganlah. (7) Kalimat imperatif pembiaran ditandai dengan kata biar atau biarkan, ditandai denan menyuruh membiarkan supaya sesuatau terjadi atau berlangsung, dapat disertai dengan pemakaian partikel-lah sehingga bentuknya menjadi biarlah atau biarkanlah.

\section{HASIL DAN PEMBAHASAN PENELITIAN}

Kalimat imperatif dapat diperinci menjadi tujuh golongan, yaitu kalimat imperatif taktransitif, kalimat imperatif transitif, kalimat imperatif halus, kalimat imperatif permintaan, kalimat ajakan dan harapan, kalimat imperatif larangan dan kalimat imperatif pembiaran.

Kalimat imperatif taktransitif dibentuk dari kalimat deklaratif (taktransitif) yang dapat berpredikat verba dasar, frasa adjektival, dan frasa verba yang berpredikat ber- atau meng ataupun frasa preposisional. Pada pidato Nadiem Makarim dalam Channel Kemendikbud RI dari tahun 2019-2021 tidak ditemukan kalimat yang mengandung imperatif taktransitif.

Kalimat imperatif transitif yang menunjukkan bahwa kebenaran bahwa si penanya yang dalam kapasitas kalimat deklaratif sebagai subjek seniman pertunjukan dapat menjadi pelengkap artis pertunjukan, sedangkan sasaran protes dalam kalimat penjelas menjadi subjek sasaran dalam kalimat dasar. Pada pidato Nadiem Makarim dalam Channel Kemendikbud RI dari tahun 2019-2021 tidak ditemukan kalimat yang mengandung kalimat imperatif transitif.

Pada pidato Nadiem Makarim dalam Channel Kemendikbud RI dari tahun 2019-2021 menunjukkan kalimat imperative halus seperti kalimat "Teruslah mengikuti anjuran bapak presiden untuk selalu menerapkan perilaku hidup bersih dan sehat, serta tetap belajar,bekrja,dan beribadah di rumah saja, Tolonglah lakukan agar kita bisa menjaga diri dari potensi terkena virus sekaligus memutuskan rantai peularan; Cobalah kita pahami bahwa pandemik bukan satu-satunya tantangan yang kita hadapi; Coba lakukan perubahan kecil didalam kelas anda". Kalimat imperative halus dalam pidato Nadiem Makarim yang ditunjukkan dengan kata tolonglah, teruslah dan cobalah

Pada pidato Nadiem Makarim dalam Channel Kemendikbud RI dari tahun 2019-2021 menunjukkan kalimat imperative permintaan seperti pada kalimat "Mohon maaf saya tidak akan memberikan janji-janji kosong kepada anda; Minta kenapa Allah". Kalimat imperative permintaan pada pidato Nadiem Makarim yang ditunjukkan dengan kata mohon dan minta.

Pada pidato Nadiem Makarim dalam Channel Kemendikbud RI dari tahun 2019-2021 menunjukkan kalimat imperative permintaan seperti pada kalimat “Ayo kita berjuang untuk kemerdekaan belajar Indonesia; Marilah kita melakukan berbagai eksperimen; Hendaknya pemuda dapat bersaing dalam peran apapun tentunya dalam hal positif; Harap kedepannya akan banyak muncul tokoh-tokoh pemuda dunia yang mendunia". Kalimat imperative ajakan pada pidato Nadiem Makarim yang ditunjukkan dengan kata ayo, 
3812 Analisis Kalimat Imperatif pada Pidato Nadiem Makarim Rekomendasi sebagai Bahan Ajar Teks Pidato Persuasif SMP - Siti Jubaedah, Hendra Setiawan, Ferina Meliasanti

DOI: https://doi.org/10.31004/edukatif.v3i6.1246

marilah, hendaknya. Kalimat imperative harapan pada pidato Nadiem Makarim yang ditunjukkan dengan kata harap.

Pada pidato Nadiem Makarim dalam Channel Kemendikbud RI dari tahun 2019-2021 menunjukkan kalimat imperative larangan seperti pada kalimat "Jangan menunggu aba-aba; Jangan menunggu perintah; Jangan menungu dunia berubah". Kalimat imperative larangan pada pidato Nadiem Makarim yang ditunjukkan dengan kata jangan

Kalimat imperatif pembiaran dapat diartikan sebagai menyuruh untuk membiarkan sesuatu terjadi atau mengambil tempat. Pada pidato Nadiem Makarim dalam Channel Kemendikbud RI dari tahun 2019-2021 tidak ditemukan kalimat yang mengandung imperatif pembiaran.

\section{Penggunaan Kalimat Imperatif pada Pidato Nadiem Makarim dalam channel Kemendikbud RI}

Kalimat imperatif merupakan kalimat yang mengandung atau meminta agar mitra tutur atau orang lain menuruti sesuatu yang dimintak sipenutur. Kalimat imperatif sangat sering digunakan saat memerinta, yang bertujuan untuk membantu memberitahu seseorang untuk melakukan sesuatu. Kalimat imperatif dapat diperinci menjadi tujuh golongan, yaitu kalimat imperatif taktransitif, kalimat imperatif transitif, kalimat imperatif halus, kalimat imperatif permintaan, kalimat ajakan dan harapan, kalimat imperatif larangan dan kalimat imperatif pembiaran.

Berdasarkan teknik bagi unsur langsung yang digunakan oleh penulis untuk menganalisis bentuk kalimat imperative ditemukan adanya bentuk kalimat imperatif, jenis kalimat imperatif dan struktur kalimat imperatif pada pidato Nadiem Makarim dalam Channel Kemendikbud RI dari tahun 2019-2021.

Kalimat imperatif halus menunjukkan sejumlah kata yang digunakan untuk menyempurnakan atau menghaluskan isi kalimat imperatif. Pada pidato Nadiem Makarim dalam Channel Kemendikbud RI dari tahun 2019-2021 menunjukkan kalimat imperative halus seperti kalimat "Teruslah mengikuti anjuran bapak presiden untuk selalu menerapkan perilaku hidup bersih dan sehat, serta tetap belajar, bekerja,dan beribadah di rumah saja, Tolonglah lakukan agar kita bisa menjaga diri dari potensi terkena virus sekaligus memutuskan rantai peularan; Cobalah kita pahami bahwa pandemik bukan satu-satunya tantangan yang kita hadapi; Coba lakukan perubahan kecil didalam kelas anda". Kalimat imperative halus dalam pidato Nadiem Makarim yang ditunjukkan dengan kata tolonglah, teruslah dan cobalah. Seperti pada kalimat "Cobalah kita pahami bahwa pandemik bukan satu-satunya tantangan yang kita hadapi", dimana dalam kalimat ini menunjukkan bahwa Nadiem Makarim meminta kita untuk memahami kondisi pandemic saat ini bukan satu-satunya tantangan yang kita hadapi artinya masih ada tantangan yang lain, penambahan partikel lah dalam kalimat cobalah menunjukkan bahwa Nadiem Makarim meminta kita secara halus.

Kalimat imperatif permintaan ditujukan untuk pertanyaan tertentu. Pada pidato Nadiem Makarim dalam Channel Kemendikbud RI dari tahun 2019-2021 menunjukkan kalimat imperative permintaan seperti pada kalimat "Mohon maaf saya tidak akan memberikan janji-janji kosong kepada anda; Minta kenapa Allah". Kalimat imperative permintaan pada pidato Nadiem Makarim yang ditunjukkan dengan kata mohon dan minta. Contohnya pada kalimat "Minta kenapa Allah" dimana kata minta menunjukkan bahwa Nadiem Makarim melakukan permintaan agar kita meminta sesuatu kepada Allah.

Kalimat imperative ajakan dan harapan digolongkan sebagai kalimat yang biasanya didahului dengan kata ayo (lah), mari (lah), harap, dan hendaknya. Pada pidato Nadiem Makarim dalam Channel Kemendikbud RI dari tahun 2019-2021 menunjukkan kalimat imperative permintaan seperti pada kalimat "Ayo kita berjuang untuk kemerdekaan belajar Indonesia; Marilah kita melakukan berbagai eksperimen; Hendaknya pemuda dapat bersaing dalam peran apapun tentunya dalam hal positif; Harap kedepannya akan banyak muncul tokohtokoh pemuda dunia yang mendunia". Kalimat imperative ajakan pada pidato Nadiem Makarim yang ditunjukkan dengan kata ayo, marilah, hendaknya. Kalimat imperative harapan pada pidato Nadiem Makarim yang ditunjukkan dengan kata harap. Contohnya pada kalimat "Ayo kita berjuang untuk kemerdekaan belajar 
3813 Analisis Kalimat Imperatif pada Pidato Nadiem Makarim Rekomendasi sebagai Bahan Ajar Teks Pidato Persuasif SMP - Siti Jubaedah, Hendra Setiawan, Ferina Meliasanti

DOI: https://doi.org/10.31004/edukatif.v3i6.1246

Indonesia" dimana kata Ayo menunjukkan bahwa Nadiem Makarim mengajak kita berjuang untuk kemerdekaan belajar Indonesia.

Kalimat imperatif larangan dapat dinyatakan dengan adanya kata jangan (lah). Pada pidato Nadiem Makarim dalam Channel Kemendikbud RI dari tahun 2019-2021 menunjukkan kalimat imperative larangan seperti pada kalimat "Jangan menunggu aba-aba; Jangan menunggu perintah; Jangan menungu dunia berubah". Kalimat imperative larangan pada pidato Nadiem Makarim yang ditunjukkan dengan kata jangan. Contohnya pada kalimat "Jangan menunggu aba-aba"dimana kata jangan menunjukkan bahwa Nadiem Makarim meminta kita untuk tidak menunggu aba-aba yang diberikan.

Pada pidato Nadiem Makarim dalam Channel Kemendikbud RI dari tahun 2019-2021 tidak ditemukan kalimat yang mengandung imperatif taktransitif, transitif dan pembiaran. Kalimat imperatif taktransitif dibentuk dari kalimat deklaratif (taktransitif) yang dapat berpredikat verba dasar, frasa adjektival, dan frasa verba yang berpredikat ber- atau meng ataupun frasa preposisional.

Kalimat imperatif transitif yang menunjukkan bahwa kebenaran bahwa si penanya yang dalam kapasitas kalimat deklaratif sebagai subjek seniman pertunjukan dapat menjadi pelengkap artis pertunjukan, sedangkan sasaran protes dalam kalimat penjelas menjadi subjek sasaran dalam kalimat dasar. Kalimat imperatif pembiaran dapat diartikan sebagai menyuruh untuk membiarkan sesuatu terjadi atau mengambil tempat.

\section{Rekomendasi kalimat imperatif pada Pidato Nadiem Makarim dalam channel Kemendikbud RI Sebagai Bahan Ajar Teks Pidato Persuasif di SMP}

Berdasarkan hasil penelitian yang peneliti temukan di lapangan dapat disimpulkan bahwa pada pidato Nadiem Makarim dalam channel kemendikbud RI menggunakan beberapa jenis kalimat imperatif. Jenis kalimat imperatif yang digunakan meliputi (1) Kalimat imperatif halus, (2) Kalimat imperatif permintaan, (3) Kalimat imperative ajakan dan harapan, (4) Kalimat imperatif larangan. Dalam kalimat imperatif halus terdapat beberapa penanda kalimat yaitu kata coba, tolong, dan silakan. Kalimat imperative permintaan ditandai dengan kata mohon. Kalimat imperatif ajakan menggunakan penanda kata ayo, mari. Kalimat imperatif larangan ditandai oleh kata jangan

Hasil penelitian ini menunjukan bahwa secara umum kalimat impereatif dapat digunakan untuk mengajak secara halus pendengar agar bisa melakukan sesuatu sesuai dengan apa yang diperintahkan pembicara. Pemanfaatan hasil analisis kalimat impertif pada pidato Nadiem Makarim dalam channel kemendikbud RI yang sudah dianalisis oleh penulis dapat direkomendasikan sebagai bahan ajar pidato persuasif di kelas IX semerter 1 Sekolah Menengah Pertama (SMP) berupa materi pidato persuasif. Bahan ajar yang akan digunakan berupa Handout, tentunya bahan ajar yang disusun sesuai dengan bidang kajiannya.

Direkomendasikan penggunaan kalimat imperatif halus sebagai bahan ajar teks pidato di kelas IX semester 1 Sekolah Menengah Pertama (SMP) yang ditandai dengan kata coba, tolong, dan silahkan dimana kalimat ini menunjukkan bahwa orang yang berpidato menghargai audiens contohnya pada kalimat "Coba lakukan perubahan kecil didalam kelas anda" dimana dalam kalimat tersebut menunjukkan bahwa orang yang berpidato mengajak audiens secara halus untuk melakukan perubahan kecil didalam kelas. Selanjutnya direkomendasikan penggunaan kalimat imperatif permintaan sebagai bahan ajar teks pidato persuasive di kelas IX semester 1 Sekolah Menengah Pertama (SMP) yang ditandai dengan mohon dan minta seperti pada kalimat "Minta kenapa Allah" dimana dalam kalimat tersebut menunjukkan bahwa orang yang berpidato meminta audiens untuk mengharapkan sesuatu kepada Allah. Kemudian direkomendasikan penggunaan kalimat imperatif ajakan dan harapan sebagai bahan ajar teks pidato di kelas IX semester 1 Sekolah Menengah Pertama (SMP) yang ditandai dengan ayo, mari seperti pada kalimat "Ayo kita berjuang untuk kemerdekaan belajar Indonesia" dimana dalam kalimat tersebut menunjukkan bahwa orang yang berpidato mengajak audiens untuk berjuang demi kemerdekaan belajar Indonesia. Terakhir direkomendasikan penggunaan kalimat imperatif larangan sebagai bahan ajar teks pidato di kelas IX semester 1 Sekolah Menengah Pertama (SMP) 
3814 Analisis Kalimat Imperatif pada Pidato Nadiem Makarim Rekomendasi sebagai Bahan Ajar Teks Pidato Persuasif SMP - Siti Jubaedah, Hendra Setiawan, Ferina Meliasanti

DOI: https://doi.org/10.31004/edukatif.v3i6.1246

yang ditandai dengan mohon dan minta seperti pada kalimat "Jangan menunggu perintah" dimana dalam kalimat tersebut menunjukkan bahwa orang yang berpidato melarang audiens untuk melakukan seusatu tanpa menunggu perintah.

Pada penelitian yang dilakukan oleh (Claria, 2021) terdapat kalimat imperative pemberian izin yang mana dapat dilihat dari adanya pemakaian kata silakan. Kalimat imperatif ini juga bertujuan agar lawan bicara dapat melakukan sesuatu seperti yang diinginkan oleh penutur. Pada penelitian ini tidak ditemukan kalimat imperative pemberian ijin maka direkomendasikan selain dari kalimat imperative yang terdapat pada pidato Nadiem Makarim dalam channel kemendikbud RI, bahan ajar teks pidato di kelas IX semester 1 Sekolah Menengah Pertama (SMP) dapat menambahkan kalimat imperative pemberian ijin dimana kalimat suruhan dalam bentuk pemberian izin ini memiliki kesan yang sopan.

Pada penelitian yang dilakukan oleh (Nanda Dwi Astri, Polma Juliati Sinambela, 2020) yang menunjukkan terdapat kalimat imperative sebagai anjuran dan kalimat imperative sebagai selamat. Pada penelitian ini tidak ditemukan kalimat imperative pemberian ijin maka direkomendasikan selain dari kalimat imperative yang terdapat pada pidato Nadiem Makarim dalam channel kemendikbud RI, bahan ajar teks pidato di kelas IX semester 1 Sekolah Menengah Pertama (SMP) dapat menambahkan kalimat imperative sebagai anjuran dan kalimat imperative sebagai selamat.

\section{KESIMPULAN}

Berdasarkan hasil penelitian yang dilakukan berkaitan dengan penggunaan kalimat imperatif. Yaitu bentuk kalimat imperatif, jenis kalimat imperatif, dan struktur kalimat imperatif pada pidato Nadiem Makarim dalam channel Kemendikbud RI tahun 2019-2021. Maka dapat diambil kesimpulan yaitu Jenis kalimat imperatif yang digunakan meliputi (1) kalimat imperatif halus terdapat beberapa penanda kalimat yaitu kata coba, tolong, dan silakan. (2) Kalimat imperative permintaan ditandai dengan kata mohon. (3) Kalimat imperatif ajakan menggunakan penanda kata ayo, mari. (4) Kalimat imperatif larangan ditandai oleh kata jangan.

Direkomendasikan penggunaan kalimat imperatif halus, Kalimat imperative permintaan, Kalimat imperatif ajakan dan Kalimat imperatif larangan sebagai bahan ajar teks pidato di kelas IX semester 1 Sekolah Menengah Pertama (SMP) seperti pada pidato Nadiem Makarim dalam channel kemendikbud RI. Direkomendasikan untuk menambahkan kalimat imperative pemberian izin, kalimat imperative sebagai anjuran dan kalimat imperative sebagai selamat sebagai bahan ajar teks pidato di kelas IX semester 1 Sekolah Menengah Pertama (SMP) yang tidak terdapat pada pidato Nadiem Makarim dalam channel kemendikbud RI.

\section{UCAPAN TERIMA KASIH}

Penulis mengucapkan terima kasih kepada para dosen pembimbing yang telah membantu menyumbangkan ilmunya guna terselesaikannya penelitian ini. Penulis juga mengucapkan terima kasih kepada keluarga dan teman-teman yang telah mendukung penelitian ini.

\section{DAFTAR PUSTAKA}

Alwi, Hasan Dkk, H. A. (2011). Tata Bahasa Baku Bahasa Indonesia. Pusat Bahasa dan Balai Pustaka.

Anak Agung Sri Darmawanti, Made Sri Indriani, M. A. (2019). Analisis Kalimat Imperatif dalam video tutorial Skincare Clarin Hayes di Youtube dan relevansinya pada pembelajaran teks prosedur di SMA. Jurnal Pendidikan Bahasa Dan Sastra Indonesia, 09(02).

Arikunto, S. (2010). Manajemen Penelitian. Rineka Cipta.

Chaer, A. (2010). Sintaksis Bahasa Indonesia. Rineka Cipta.

Claria, D. A. K. (2021). Sosialisasi Penggunaan Kalimat Imperatif Sebagai Strategi Pemasaran UMKM pada 
3815 Analisis Kalimat Imperatif pada Pidato Nadiem Makarim Rekomendasi sebagai Bahan Ajar Teks Pidato Persuasif SMP - Siti Jubaedah, Hendra Setiawan, Ferina Meliasanti

DOI: https://doi.org/10.31004/edukatif.v3i6.1246

Masa Pandemi Covid-19 di Desa Pejeng Gianyar. Jurnal Abdidas, 2(3), 472-482.

Finoza, L. (2013). Komposisi Bahasa Indonesia. Diksi.

Heryanto, R. A. (2019). Peningkatan Kemampuan Berpidato Persuasif dengan Menggunakan Media Barang Produk Pada Siswa Kelas XI IPA SMA Negeri 1 Turi Tahun Pelajaran 2018/2019. Skirpsi Universitas Sanata Dharma.

Izhar. (2015). Pengungkapan Makna Imperatif dalam Komunikasi Jual Beli. Jurnal Pesona, 3(2), 71-85.

Lexy J Moleong. (2016). Metode Penelitian Kualitatif. Remaja Rosda Karya.

Lindawati. (2015). Kalimat Imperatif Bahasa Kepulauan Tukang Besi. Jurnal Humanika, 3(15), 5.

Nanda Dwi Astri, Polma Juliati Sinambela, A. Y. P. (2020). Kalimat Imperatif Dalam Bahasa Batak Toba Desa Mela Kecamatan Tapian Nauli Kabupaten Tapanuli Tengah. Jurnal Sastra, 9(2).

Novitasari. (2011). Kalimat Imperatif Bahasa Minangkabau. Minangkabau Press.

Nurul Fahmi, Saifuddin Mahmud, A. A. (2018). Analisis kalimat Imperatif yang digunakan Guru dalam Pembelajaran Bahasa Indonesia di SMA Inshafuddin Bandar Aceh. Jurnal Ilmiah Mahasiswa Pendididikan Bahasa Dan Sastra Indonesia, 3(3).

Nuryani. (2014). Kalimat Imperatif dalam Bahasa Jawa. Jurnal Dialektika, 1(2), 182-192.

Ramlan. (2010). Ilmu Bahasa Indonesia Sintaksis. CV. Karyono.

Saputri, A. D. (2017). Penggunaan Kalimat Imperatif oleh Guru dalam kegiatan pembelajaran Bahasa Indonesia di SMP Negeri 13 Kota Magelang. Skripsi Universitas Negeri Yogyakarta.

Sudaryanto. (2015). Metode Penelitian kuantitatif, kualitatif \& $R \& D$. ALFABETA.

Sugiyono. (2018). Metode penelitian kuantitatif, dan kualitatif dan $R \& D$. Alfabeta.

Youtube. 2019-2021. Channel Kemendikbud RI. Tersedia: https://www.youtube.com/channel/UCH9AFSwY4WqgHoCLG2XIveg. [20Juni 2021] 